\title{
Urban Community Development and Private Education Dilemma: Based on a Field Study of a City in East China
}

\author{
Li Qian ${ }^{1^{*}}$, Jing Anlei ${ }^{2}$ \\ ${ }^{1}$ Institute of Higher Education, Beijing Normal University, 100875, Beijing, People's Republic of China \\ ${ }^{2}$ China's National Education Examinations Authority, People's Republic of China \\ *Corresponding Author: liqian08@mail.bnu.edu.cn
}

Copyright (C) 2014 Horizon Research Publishing All rights reserved.

\begin{abstract}
Urbanization is an issue of universal concern today distinctly affecting the supply, content, and orientation of education. Based on a field study in a city in East China, the article argues that rural-urban migration in the process of urbanization created private sectors in education enterprises that were in sync with the urban community expansion. During the rapid development to escape the curse of underdevelopment, the local government unveiled substantive policies and regulations to welcome private capital to engage in education, and to encourage teachers to mobilize from public schools to private schools. With the excess demand for education, the preferential policies and a large number of teachers gave up tenure at public schools, and local private education developed rapidly in terms of number, size and quality. However, the "non-elite" characteristic of both urban and rural private schools was doomed to face dilemma when the ever-changing rural population composition and the differential treatment to public schools and private schools in public policies caused a decline in the number of rural schools and an increase in teachers' turnover rate. For a sustainable development of local private education, education quality enhancement and policy adjustment shall be a must.
\end{abstract}

Keywords Urban Community, Urbanization, Private Education, Dilemma

\section{Introduction}

China's huge population base created an extensive education demand and a mammoth public school system. To meet the huge demand and to improve education service, the Chinese government issued the Decision of the Reform of Education System in 1985, decentralizing and diversifying the providing and financing of education. In 1992, the late leader Deng Xiaoping made his Southern Tour and reinvigorated Chinese economic reform and opening up. In June, the State Council, or China's Cabinet, published the Decision of Accelerating Tertiary Industry Development, in which education was ranked as the basic industry of nationwide significance. ${ }^{[1]}$ The 14th National People's Congress in October established the market economic system of socialism in China, and brought two historical phenomena in education field. The one was a higher enthusiasm of social capital participating in education, and the other was a rapid scale expansion of existing schools. ${ }^{[2]}$ Since then, private schools went into a phase of explosive growth, and helped invigorate Chinese education by providing decentralization and competition. In 1997, the State Council promulgated Regulations on the Running of Educational Institution, which is the first administrative regulation to regulate private education. In the $3^{\text {rd }}$ National Education Conference in 1999, private education was first positioned as being "equally important as public education" instead of being "supplementary to public education". Private education had been exceptionally prosperous by 2003, with the number of students increased from 2.3 million in 1996 to 14.2 million (Table 1).

Table 1. Scale and Proportion of Chinese Private Education (1996-2003)

\begin{tabular}{c|c|c|c|c|c|c}
\hline & 1996 & 2000 & 2001 & 2002 & 2003 \\
\hline \multicolumn{5}{c|}{ The number of students of all levels of education (million) } \\
\hline Nationwide & 240.6 & 249.7 & 249.0 & 252.8 & 255.3 \\
\hline $\begin{array}{c}\text { Private } \\
\text { education }\end{array}$ & 2.3 & 7.0 & 9.2 & 11.2 & 14.2 \\
\hline $\begin{array}{c}\text { \% of total } \\
\text { schools }\end{array}$ & 1.0 & 2.8 & 3.7 & 4.4 & 5.6 \\
\hline \multicolumn{4}{c}{ The number of students of education with degree (million) } \\
\hline Nationwide & 201.3 & 214.4 & 215.7 & 218.6 & 219.1 \\
\hline $\begin{array}{c}\text { Private } \\
\text { education }\end{array}$ & 1.0 & 3.2 & 4.7 & & 9.8 \\
\hline $\begin{array}{c}\text { \% of total } \\
\text { schools }\end{array}$ & 0.5 & 1.5 & 2.2 & & 4.5 \\
\hline
\end{tabular}

Note: "All levels of education" refers to kindergarten, regular primary schools, regular junior secondary schools, secondary vocational schools and higher education institutions.

Source: Department of Development Planning, Ministry of Education. The thought and policy of Chinese private education (report outlines). 2004.

According to the widely recognized classification of the developing stages of Chinese private education, there were three stages before 2003, namely recovery stage (1978-1991), 
rapid development stage (1992-1997) and standardization stage (1997-2002).${ }^{[3]}$ The year 2003 witnessed the arrival of a new stage of private education, and the Law for Promotion of Private Education (LPPE) implemented in October $28^{\text {th }}$, 2002 made several regulation adjustments to promote private education. For example, it legitimized the involvement of public schools in the establishment of private schools and enabled private schools to make a profit. $L P P E$ was crowned as "the milestone in the history of Chinese private education", and of epoch-making significance in accelerating the transformation of private education development pattern. ${ }^{[4]}$ With strong support from the central government, private education market continued to heat up, and experienced years of rapid and sustained growth (Table 2).

Since most private schools engaged in compulsory education were distributed in cities, countries and towns, $\angle P P E$, to a very great extent, changed the direction of Chinese private education policy. After 2003, local government worked more actively and gave more support to local private education, and the central government acted more like a supervisor and regulator. ${ }^{[5]}$ Locally-driven model gave birth to innovations in policy and practice, which embedded in the bigger social context of high-speed urbanization during the past decades when China became the world's largest urban nation with over 600 million urban citizens. It was recognized that the role of urbanization and the development of urban community had been especially important both in the transformation of Chinese society and the development of Chinese education industry. Within this context, this paper presents a discussion of local private education in the historical process of urbanization, based on a field research in a prefecture-level city in east China.

Table 2. The Development of Chinese Private Education (2003-2011)

\begin{tabular}{|c|c|c|c|c|c|c|c|c|c|c|}
\hline & & 2003 & 2004 & 2005 & 2006 & 2007 & 2008 & 2009 & 2010 & 2011 \\
\hline \multirow{2}{*}{$\begin{array}{c}\text { All levels of private } \\
\text { education }\end{array}$} & NSI & & 7.85 & 8.62 & 9.32 & 9.52 & 10.09 & 10.65 & 11.9 & 13.08 \\
\hline & NS & 1420 & 1769.36 & 2168.1 & 2313.02 & 2583.50 & 2824.4 & 3065.39 & 3392.96 & 3713.90 \\
\hline \multirow{2}{*}{ Private kindergarten } & NSI & 5.55 & 6.22 & 6.88 & 7.5426 & 7.7616 & 8.3119 & 8.9304 & 10.2289 & 11.5404 \\
\hline & NS & 480.23 & 584.11 & 668.09 & 775.69 & 868.75 & 982.03 & 1134.17 & 1399.47 & 1694.21 \\
\hline \multirow{2}{*}{$\begin{array}{l}\text { Private regular } \\
\text { primary schools }\end{array}$} & NSI & 0.5676 & 0.6047 & 0.6242 & 0.6161 & 0.5798 & 0.5670 & 0.5496 & 0.5351 & 0.5186 \\
\hline & NS & 274.93 & 328.32 & 388.94 & 412.09 & 448.79 & 480.4 & 502.88 & 537.63 & 567.83 \\
\hline \multirow{2}{*}{$\begin{array}{l}\text { Private regular junior } \\
\text { secondary schools }\end{array}$} & NSI & 0.3651 & 0.4219 & 0.4608 & 0.4550 & 0.4482 & 0.4408 & 0.4331 & 0.4259 & 0.4282 \\
\hline & NS & 256.57 & 315.68 & 372.42 & 394.06 & 412.55 & 428.4 & 433.89 & 442.11 & 442.56 \\
\hline \multirow{2}{*}{$\begin{array}{l}\text { Private regular high } \\
\text { schools }\end{array}$} & NSI & 0.2679 & 0.2953 & 0.3175 & 0.3246 & 0.3101 & 0.2913 & 0.267 & 0.2499 & 0.2394 \\
\hline & NS & 141.37 & 184.73 & 226.78 & 247.72 & 245.96 & 240.30 & 230.13 & 230.07 & 234.98 \\
\hline \multirow{2}{*}{$\begin{array}{l}\text { Private secondary } \\
\text { vocational schools }\end{array}$} & NSI & 0.1382 & 0.1633 & 0.2017 & 0.2559 & 0.2958 & 0.3234 & 0.3198 & 0.3123 & 0.2856 \\
\hline & NS & 79.38 & 109.94 & 154.14 & 202.63 & 257.54 & 291.81 & 318.1 & 306.99 & 269.25 \\
\hline \multirow{2}{*}{$\begin{array}{c}\text { Private higher } \\
\text { education institutions }\end{array}$} & NSI & 0.0173 & 0.0228 & 0.0547 & 0.0596 & 0.0615 & 0.0640 & 0.0658 & 0.0676 & 0.0698 \\
\hline & NS & 81 & 139.75 & 212.63 & 280.49 & 349.69 & 401.3 & 446.14 & 476.68 & 505.07 \\
\hline \multirow{2}{*}{$\begin{array}{l}\text { Private non-academic } \\
\text { educational training } \\
\text { organizations }\end{array}$} & NSI & & & 2.9048 & 2.3470 & 2.2322 & 1.9579 & 1.9395 & 1.8341 & 2.1403 \\
\hline & NTP & & & 889.5 & 876.84 & 884.68 & 834.76 & 844.93 & 929.78 & 955.46 \\
\hline
\end{tabular}

Note: (1) "All levels of private education" refers to private kindergarten, regular primary schools, regular junior secondary schools, secondary vocational schools and higher education institutions. It contains no private non-academic educational training organizations. (2) NSI refers to "the number of schools or institutions"; NS refers to "the number of students"; NTP refers to "the number of trained people".(3) Counting unit is 10 thousand.

Source: Statistic Bulletin of the National Education Development of the People's Republic of China, 2003-2011. 


\section{Literature Review}

\subsection{Urbanization and Urban Community Development}

The growth of urban communities and the urbanization is one of the most impressive facts of modern times. "Urbanization" refers to the process by which rural areas turn urbanized as a result of economic development and industrialization, ${ }^{[6]}$ and in which an increasing proportion of an entire population lives in cities and the suburbs of cities. The term urbanization represents the level of urban relative to overall population, or it can represent the rate at which the urban proportion is rising. ${ }^{[7]}$ It is not merely a modern phenomenon because a rapid move in urbanization has been occurring around the entire world since $1800,{ }^{[8]}$ and the history of developed and urbanized countries indicates also three stages in the development of urbanization: stage of growth, stage of development, and stage of mature. ${ }^{[9]}$ There are a variety of distinctive features of China's urbanization compared to developed countries, for example the high rate of urban population growth, the large and growing urban-rural income gap, "too many cities, too few people", the unique economic structure of cities, and also the strict administrative hierarchy of cities. ${ }^{[10]}$

Urban community or city, comprising a large aggregation of people living primarily off non-agricultural pursuits, ${ }^{[11]}$ can be traced back to ancient Mesopotamian city Babylon 5,000 years ago ${ }^{[12]}$ and Xia dynasty known as "Yi" during the $21^{\text {st }}$ century $\mathrm{BC}$ to $17^{\text {th }}$ century $\mathrm{BC}$, and it has been the center of education, religion, commerce, and political power since the earliest origin. Despite its historical legacy, urban community has grown significantly in size and number only during the last 200 years, for the advent and spread of industrialization and the global population explosion accelerated the process of urbanization. The characterization of a community as urban or as city can be on the basis of size, the number of inhabitants, and the heterogeneity of its population. ${ }^{[13]}$ In China, cities designated by the State Council and other places with density of 1,500 or more per sq. $\mathrm{km}$ can be defined as urban area. ${ }^{[14]}$ Three administrative types of cities in China are 1) provincial-level municipalities; 2) prefecture-level cities; 3) country-level cities, and 4) administrative towns. ${ }^{[15]}$

\subsection{Education Marketization and Private Education}

Over the past decades, the relationship between the state and the market shifted considerably due to the massive economic, political, and cultural change. In western countries, Neoliberalism convinced the government and the general public that a strong market would provide desired prosperity to public service, ${ }^{[16]}$ and the marketization and accountability of public education became prevalent. In China, socialist market economy welcomed the development of "quasi-market" in non-governmental public service. As Levacic suggested, the distinguishing characteristics of a quasi-market for a public service were "the separation of purchaser from provider and an element of user choice between providers". ${ }^{[17]}$ The application of market principles in education in China led to the rise of private schools, shifting education responsibilities from underfunded government to nonprofit organizations. Carnoy \& Samoff saw private education in developing countries as an inescapable solution to the demand for education, particularly at the secondary level. ${ }^{[18]}$ And the increasing number of private providers of education in China, especially the compulsory education, deserves attention.

\subsection{Relations between Education and Urbanization}

The urbanization of education is an important part of the overall process of urbanization and social transformation. During the earlier stage, urban population increased and the limits of urban community extended to create enlarged class sizes, overcrowded buildings, and new campuses in the outskirts of urban community. S.M. Brownell observed that schools in the 1960s faced two special problems caused by the change in the nature of the population. One was the problem of re-educating teachers; the other was the role of the school as a community one. ${ }^{[19]}$ James B. Conant, former president of Harvard University, saw the stratification and segregation of students along socio-economic line caused by big city development as a serious problem. Robert J. Havighurst, in his paper "Urbanization and Education in the United States", explored the effects of urbanization upon the school system, metropolitan development, attendance at non-public schools, and the urban-community school. He proposed that the secondary school in the big city did not simply reflect the structure of the community of today, but also influenced the structure of the community of tomorrow. [20] Edmund King discussed the connection between urbanization and education in Britain. To him, education was an instrument for reconstructing society. ${ }^{[21]}$ Saburi Biobaku believed urbanization raised several crucial problems in developing countries. It was both a disruptive and modernizing force in Nigeria, and it broke down the traditional concepts of education. ${ }^{[22]}$

Zhang Z.Z. found a non-linear relationship between city development and higher education development. The higher education did not keep a synchronous growth with city expansion. ${ }^{[23]}$ Wang S.F.'s research on higher education and regional economy showed that before the average GNP reached 2000 dollars, it was possible to see rapid development of both the urban community and its education. However, once the average GNP raise up to 5000 dollars, the development of education tended to be relatively slower. ${ }^{[24]}$ Wen J.H. \& Han Y.Q. made an empirical study on the correlation of urbanization and higher education in Wenzhou, a developed city in south China. The Pearson correlation of its urbanization rate and higher education scale indicated that urbanization was significantly and positively correlated with higher education development in the context of Wenzhou $(\mathrm{R}=0.951) .{ }^{[25]}$ Yang D.P. elaborated on the consequences of rapid urbanization in China, one of which was the policy of 
"dismantling teaching points and combining schools" and the crisis of rural schools. ${ }^{[26]}$ Wang J.T. \& Cui F.Y. used the econometric annalistic method to examine the relationship between China's population education structure and urbanization. The study found that the population education structure is the Granger reason for urbanization, and the different education hierarchical has different contribution to urbanization. ${ }^{[27]}$

\section{Methodology}

To explore the local private education development embedded in the context of urbanization, a field research was conducted at a city (City S) in Jiangsu province in east China. The city was found in 1996, with a large population, a weak economic foundation and lagging social undertakings. Without high-quality education resources, it narrowly met the national standards of popularizing nine-year compulsory education, and the rate of admission into high schools was as low as $31 \%$. However, notable progress has been made in the economy and education during the past decades.

The research gained wide supports from local education departments, statistics offices, and private schools. It was divided into three stages. In the first stage (the first half of May), we contacted the Bureau of Education of City S, and asked about the possibility of a field research on private education. The Bureau welcomed us to City S, and confirmed the schedule. After then, we did an internet search for information relevant to City $\mathrm{S}$, based on which research questions and interview outline were developed tentatively. In the second stage (May $19^{\text {th }}$ to $27^{\text {th }}$ ), a field research was conducted in City S (May $19^{\text {th }}$ to $20^{\text {th }}$ ), country Y (May $20^{\text {th }}$ to $23^{\text {th }}$ ), country $\mathrm{H}$ (May $24^{\text {th }}-25^{\text {th }}$ ), and the capital city $\mathrm{N}$ of the Province (May $26^{\text {th }}-27^{\text {th }}$ ). In City S, we held discussions with the vice director of the Bureau of Education of City S, and held three symposium with officers from the office of private education and the department of educational statistics. In country $\mathrm{Y}$, we first held a discussion conference with officers from local Bureau of Education, Bureau of Finance and Bureau of Statistics. After studying the distribution and types of local private schools, we chose 6 ones to investigate. Among the 6 private schools, Yin He Secondary School, provided elementary and secondary education, was invested by entrepreneurs and purchased by a famous education investment group. Xiu Yuan, a complete high school, was run by a group of educators, retaining the characteristic of no investment from entrepreneurs. Nan Yang School adopted the "public-owned, privately-operated" mode, and was closely connected to the best public high school in country Y. Hong Yan School was the only existing private school in rural areas. Besides the 4 schools above, a primary school (Huai Wen Primary School) and a kindergarten with a large number of students (Youth Square Kindergarten) were selected. In country $\mathrm{H}$, an informal discussion was conducted with local Bureau of Education. And two private
schools---Hong Xiang Secondary School and Yu Cai Experimental School were selected to conduct field investigations. In the 8 schools, in-depth interviews with school administrators, teachers, and students were conducted separately, and classroom observations were a must. Also, the first page of annual check-up report was photocopied for further study in each school. Afterward, we went to Provincial Education Department in the capital city N, from where we interviewed the Directors in charge of provincial education development planning, private education, and higher education. In the third stage (June, 2012), interviews were transcribed and analyzed with an interpretive approach. Several exchange and communication with schools mentioned above were made. Subsequent questionnaire on the background of the samples of students was designed and completed to confirm the findings from interviews.

\section{Findings and Discussions}

\subsection{Profile of Urbanization and Local Private Education}

In 1996, City S was built as a new prefecture-level city and "its urban population was $10.1 \%$ of the total". The government documents revealed that great emphasis had been placed on the transformation and the extension of urban areas, industry upgrading, and the improvement of regional economy based on urban centers. The annual data on record showed that urbanization in City $\mathrm{S}$ took place at a fast rate in the past decade. In 2002, population residing in urban areas was $28.7 \%$, and the share increased to $43.3 \%$ by 2010 according to official census conducted in 2011 (Table $3)$.

Table 3. Urbanization Rates ( $\%$ ) of City S and Its Two Countries (2002-2010)

\begin{tabular}{c|c|c|c|c}
\hline Year & National & City S & Country Y & Country H \\
\hline 2002 & 39.1 & 28.0 & 32.1 & 22.6 \\
\hline 2003 & 40.5 & 31.0 & 20.0 & 15.4 \\
\hline 2004 & 41.8 & 30.1 & 24.8 & 24.8 \\
\hline 2005 & 43.0 & 31.5 & 22.7 & 29.1 \\
\hline 2006 & 43.9 & 32.4 & 26.1 & 29.9 \\
\hline 2007 & 44.9 & 34.1 & 27.9 & 31.6 \\
\hline 2008 & 45.7 & 35.9 & 29.6 & 33.3 \\
\hline 2009 & 46.6 & 37.7 & 32.5 & 34.2 \\
\hline 2010 & 47.5 & 48.1 & 47.4 & 41.7 \\
\hline
\end{tabular}

Source: 2011 National Statistical yearbook \& Statistical yearbook of City S

City $\mathrm{S}$ epitomized the rapid urbanization and industrialization in whole China, though its rate was no faster than the national level largely because the local economy was starting from a very low base. The local government paper looked back into the past years and 
described the newly founded city as "economically poor and culturally blank" during 1996-1999. In fact, before the founding of City $\mathrm{S}$ in 1996, non-degree private education had developed to a certain scale and "the social capital had the desire to enter into educational business". Promoted by central government policy on running schools by non-government sectors, private schools offering degree courses emerged in a relatively small number. According to the field research involved different private schools in City S, we found private investment in education was mainly from society groups investment, public school investment, with businesses investment contributing a quite smaller share. This pattern had much to do with local government's financial difficulties in the earlier years. However, data provided by the local government showed that the number of local private high schools increased from 5 in 1999 to 36 in 2005, and then started falling (Table 4). Also, it was in 2005 when the number of all levels of private schools increased to 973 (tripled that in 1999) and the number of students in private schools was as large as 296 thousand (sixteen times that in 1999) (Table 5).

Table 4. Development of Private High Schools in City S (1999-2007)

\begin{tabular}{c|c|c|c|c|c|c|c|c|c}
\hline Year & 99 & 00 & 01 & 02 & 03 & 04 & 05 & 06 & 07 \\
\hline $\begin{array}{c}\text { Number of } \\
\text { private } \\
\text { high } \\
\text { schools }\end{array}$ & 5 & 13 & 15 & 21 & 29 & 34 & 36 & 31 & 26 \\
\hline
\end{tabular}

Source: Local government's internal document on the development of local private education, 2008.

Table 5. Decline in the Number of Private Schools in City S since 2005

\begin{tabular}{c|c|c}
\hline Year & $\begin{array}{c}\text { All education } \\
\text { institutions }\end{array}$ & $\begin{array}{c}\text { Private education } \\
\text { institutions }\end{array}$ \\
\hline 2005 & 1714 & 973 \\
\hline 2006 & 1646 & 915 \\
\hline 2007 & 1510 & 816 \\
\hline 2008 & 1241 & 340 \\
\hline 2009 & 1233 & 354 \\
\hline
\end{tabular}

Note: "education institutions" refer to all levels of schools with records of formal schooling and kindergartens.

Source: Statistical yearbook of City S (2006-2010)

It was evident that the year 2005 was a watershed in the history of local private education development, and since then, government policy on regulating private sector and the power of market on eliminating the underperforming schools led to a decline in the number of private schools. It was believed that the passage from laissez-faire before and policy tightening after was a great factor influencing local private education development, and it was much more consistent with the change in government financial strength and its susceptibility to education market disorder. Beyond that, the different contents and quality of local urbanization before and after drove the process further. To make sense of the influences from rapid urbanization and government actions, we divided the private education development into two meaningful stages. Though the two-stage division is not perfectly neat, we claim here that it is not an unwarranted exercise and it is instrumental to understanding reality.

\subsection{Former Stage: Insufficient Education Finance, Laissez-faire, and Extensive Urbanization}

At the earlier years, City $S$ was known for its underdeveloped economy, the large proportion of agricultural population and the high agricultural production value. To accelerate industrialization, local government encouraged rural workforce to enter into non-agricultural industries and farmers turned to be workers in cities. The term "farmer-turned migrant workers" was coined in the past decade to describe the new stratum that worked for urban construction but didn't have the identity of urban residents. City S, however, couldn't provide enough jobs for its surplus rural labors and a large number of rural labors got jobs in well-developed areas outside their hometown. For a long time, the population outflow was serious in City S. At the same time, strict resident registration system in China made migrant workers hardly obtain new residence identities and the children cannot attend certain schools in the cities where their parents are working. Children were left behind in the rural area, in the custody of relatives or grandparents, and the schooling of unattended children in hometown became the priority of migrant-worker families.

All local private schools were boarding schools or divided resident students and nonresident students into different classes. The interview with school administrators and teachers presented us a picture that half of students in urban private schools came from rural areas, whose parents worked in cities (either in City $\mathrm{S}$ or other cities).The competitive advantages were embodied in the number and the condition of students' dormitories for boarders. "Around 2003, students attended urban public schools were mostly commuters. Private schools seized the opportunity to construct resident buildings, improve boarding facilities and recruit full-time teachers responsible for the daily life of students from rural areas". In a private primary school, every resident building was supervised by 10 full-time teachers and 2 dormitory keepers on duty. Students were encouraged to look after themselves in daily life, but most students at low grades need help and care. Teachers responsible for students' daily life "did laundry", "made beds", "helped students brush teeth", and "supervised students". These teachers' salaries were low. They rose early and went to bed late. Some of them lived in dormitories and ate with students in canteens. "Children need supportive love and nurturing care from the adults. When parents were not available, teachers took over the work".

It seemed that the survival of private education was based on heterogeneous demand, for example, the demand for boarding and daily care. In fact, most students and parents 
admitted that they would choose public schools if there's no restriction on school district housing and household register status. Private school didn't have these restrictions and was a "second-best choice". Even without these restrictions in social system, the demand to attend public schools was still hard to be satisfied due to government's weak financial support for education and scarce public education resources. The data provided by local government revealed that more than $1,000,000 \mathrm{~m}^{2}$ school buildings were in a state of disrepair in 2000. A minimum of 400 million Yuan was needed for the renovation of dilapidated buildings, but local government's fiscal avenue totaled 1.1billion Yuan with only 680 million available as fiscal resources. In addition, school-age population increased during the late 1990s, and the huge education demand could hardly be digested by the public sector. Take the year 2000 as an example. Only $47.8 \%$ of local junior high school graduates entered senior high school or vocational schools, while the provincial average level was $22 \%$ higher. In this sense, local private education sprung up based more on "excess demand" rather than heterogeneous demand, which somehow verified the idea proposed by E. James that "excess demand-driven private sectors are found primarily in developing countries" [28].

Given the "excess demand" and the considerable fiscal pressure, the government adopted laissez-faire policy encouraging multi-investment and super-loose development environment for the private sector. It was during this period that many teachers gave up the "tenure" in public schools to join private schools for higher salaries, or set up private schools of their own. The mobilization of public schools teachers to private schools, to some extent, brought life to private education. Three reasons accounted for the positive circulation of teachers from public schools to private schools. The first one was the newly established local government with limited financial capacity couldn't even afford the salary of public school teachers. The second was the market-oriented reform nationwide since 1978 did bring new ideas to education field and lots of teachers considered "regular salary until retirement regardless of performance in public system" less attractive than "flexible performance-based salary in private system". The third was the encouragement of local government. For example, it was promised that there would be no institutional barriers for teachers who wanted to come back from private schools to public system in the future. However, these favorable reasons turned out to be unfavorable ones as the fiscal finance became stronger, the government tightened polices and the course of urbanization changed.

\subsection{Later Stage: Stronger Education Finance, Policy Tightening, and Urbanization Transformation}

After several years of development, the economic gap between City S and other cities had been greatly reduced. On the one hand, local government's effective effort of "inviting investment" stimulated job growth. On the other hand, amidst 2008 global financial crisis, national unemployment headed up, and random dismiss, wage arrears, overdue insurance became prevalent in some labor intensive industries. A large number of migrant workers returned to City S. Though urbanization rate was on the rise as shown in Table 3, the mechanism was different. Most of these ex-migrant workers didn't back to rural areas. They flocked to urban centers or small-towns. The field study revealed that "small-town construction" in City S was of strategic significance, during which "small towns became functioning population centers attracting a large number of rural immigrants worked there or resided there". Towns or cities generated jobs and income, and the increase in population density was conductive to delivering education more efficiently. At the same time, urbanization and industrialization reinforced each other, giving rise to the further development of private sector, particularly the private education, in response to a growing number of city residents. According to the background survey of sample students in 4 private urban schools, native urbanites were not in the majority. $70.1 \%$ of 392 students were of rural origin, but their identities were quite confusing. Some of them were "at the boarding class, living at school and going home in rural area once a month". Some of them "lived with grandparents or parents in rented apartments". Also, some of them "lived with relatives in the city", and during summer holidays, the parents would "pick them up and take them to where they work".

Being asked why they choose private schools, students mentioned the hope their parents held that sending children to urban schools would provide them a much better education. Administrators expressed the view that parents living in the same neighborhood or working in the same factory tended to send their children to same schools. On one side, "peer-group effect" was more evident than ever. On the other side, income disparity increased with the economic and social development, and high-income families emerged in City S. They had prominent demand for high-quality education, which could be interpreted as the rise of "heterogeneous demand" for education resources. In response, local private schools had got to "create a good brand image", "improve teaching quality", "innovate on educational ideas", "explore modern school system", "excavate a comparative superiority", "optimize education resources" and "develop features different from other schools". Quoted a leader of the Bureau of Education, "the local education resources had been largely saturated after 6 years of mushroom growth, which resulted in the increasing heat of competition between public schools and private schools......The extensive development pattern, relying on material construction and enrollment expansion, was to be replaced by the refinement model of development".

The transition of development strategy was not an easy but a necessary choice for private schools after the mid of 2000s. Central and local governments' financial resources became wealthier and the central and provincial financial 
input to public schools had been increasing greatly each year. The hardware construction, teacher professional development and salaries were improved significantly; private schools lost their comparative advantage in school conditions and performance-based salaries. "Essentially, the teacher flow from public schools to private schools ceased in recent years and lots of teachers returned to public schools through open recruitment". In this circumstance, these private schools without high quality, good reputation and favorable characteristics went into a vicious cycle and the government began to quicken the pace of policy tightening. First, "in the years ahead, new private schools for compulsory education and private high schools in rural areas could not be approved to set up" since the government statistics showed that primary and secondary education resources had already saturated in the past years and tended to have a crisis of surplus. Second, systems of annual inspection, stricter approval and censor, property rights monitoring and alteration, and income distribution had been established to neaten the local education market. Third, the government speeded up education resources adjustment and integration after 2000. A specific policy package was issued, one of which proposing "school transfer", "capital increase and share expansion", "school-enterprise liaison", "mergers and acquisitions", "the formation of education group", etc. to accelerate the flowing of high-quality resources to elite schools. Some schools closed down under the pressures of "uneasy" policy environment and fierce market competition, while some private schools survived and continued to grow.

\subsection{Private Education Dilemmas}

Urbanization and the expansion of urban communities laid the foundations for the development of private education, which in turn promoted the further development of urban areas and the level of urbanization. In the mutually influenced process, urban private schools had made significant advances these years while rural private schools faced the existential crisis. In country $\mathrm{H}$, no rural private schools except several illegal private kindergartens existed. In country $\mathrm{Y}$, only one rural private middle school was in operation, and struggled to maintain the business scale. Ten years ago, the dispersed village public schools with very small class size turned out to be a waste of insufficient education resources. National reform on the distribution of rural schools was undertaken with the dismantling of teaching points and the combination of small schools. Students in rural areas were gathered in combined schools in towns. The great distance between the school and the home made many parents send children to private schools closer to home. In this sense, students from rural areas were the lifeblood of rural private schools. These years, the expansion of urban areas, the development of transportation and the innovation in urban-rural construction led a change in people's attitudes toward spatial distance, money-making opportunity and education access. In Hong Yan School, the only remaining private secondary school in rural area, the schoolmaster and teachers lived in schools to give 24-hour care to students. The vice principle went from house to house in the vicinity, persuading parents to send children to the school. "Urban public schools and private schools competed for talented students, and rural public schools with government funding rested easy with the loss of local students. For rural private school, it was a nightmare". "Most students in our school were poor in academic study. But we had no choice. They were our source of income". "We never thought of giving up. Instead, we helped every student make up the lessons they had missed and taught them again and again until they understood. For this, much time was devoted to the student". Or rural schools would stand empty as rural parents make a mad rush for urban schools.

In fact, it's no better in urban private schools. There were several restrictions on student admissions in urban private schools. As the admission policy stood, students in compulsory education continued their studies by progressing from kindergarten to primary schools, and from primary schools to secondary schools. The policy, however, ruled private schools out. Besides, education expenses required by private schools blocked out many students from economically disadvantaged families. Occasionally, "the State commodity price department showed disapproval of the charging standard set by private schools and the fees for students in some grades were even capped at uneconomic rates". At the same time, the school-age population showed the tendency to decline in recent years. The lack of prospective students has become a serious issue for urban private schools. In addition to this, the inclination of strong protection of public schools was revealed through increased education budget by central government and direct interference by local government, which limited the development of private schools and made them become less selective in admission process.

Urbanization did not attract labors from rural areas to urban areas; it attracted teachers, too. "Recent years, high turnover rate of teachers was a serious problem with detrimental effects on the sustainable development of private education". Both rural and urban private schools were challenged. In rural private schools, younger teachers thought of "gaining two-to-three-year teaching experience, and going to better schools in urban areas". In urban private schools, teachers thought of "being excellent in teaching and going to public schools or going to schools in larger cities". An official survey of teacher demography in 2008 indicated that $41 \%$ of private school teachers came from public schools, $46.2 \%$ was recruited from university graduates, $2.6 \%$ was rehired after retirement, and $1.6 \%$ changed the former profession to be teachers. The local government issued several supportive policies on the equal treatment of teachers in private schools and public schools. In fact, private school teachers did not have equal access to the welfare and fringe benefits that public school teachers enjoyed. For example, public schools provided teachers public institutions insurance, while most private schools teachers were provided with corporate insurance. The two 
kinds of insurances were different not only in monthly premiums but in job stability, which contravened the commitments in "Suggestions on Accelerating Private Education Development in City $S$ " issued by local government in 2006. In addition, as noted before, the relative advantage of salaries of private school teachers diminished gradually when salaries paid by central government and local government to teachers in public schools increased rapidly these years. The stability of teachers in private schools posed a grave threat to the sustainable development of private education.

\section{Conclusions}

Urbanization is a topic of universal interest today obviously affecting the supply, content, and orientation of education for its close connection to social development. Rural-urban migration would create private sectors in education enterprises that were in sync with the urban community expansion. In City S, rapid urbanization from 2002 to 2011 boosted growth in economy, social productivity and manpower requirements; and the education market and urban immigrants provided unique opportunities and the private sector expended both in number and size. A surge in private education supply in the past decade, though partly due to the policy support from local government, could be explained largely by the excessive educational needs of children of rural workers in cities. Though the field study identified education demand as the mediator between urbanization and private education development, the interview-based methodology could hardly, in a clear-cut way, distinguish excess demand from heterogeneous demand. In the first stage of local private education development, favorable policies were made to support the private sector and those people devoting to the public education given poor financial support. Excess demand was more adequate in the explanation of private school growth, especially the prosperity of private boarding high schools. In the second stage, the quality and content of local urbanization were different. Stricter policies were issued to strengthen the governmental function in macro control and market economy coordination given the greatly enhanced financial strength. Excess demand still had a great effect in this stage while heterogeneous demand was increasingly evident when parents preferred all-level schools in urban centers and high-income family began to be different interest groups with differentiated education demands.

To some extent, the level urbanization depended on the development of education, especially the private education with flexibility to ever-changing market opportunities and education demands. Education was a significant contributor to urbanization in City S, as people mobilized in search of social and economic opportunities. Different from many industrialized western countries whose urbanization preceded education marketization, China's market-oriented reform in education was embedded in the rapid progress of urbanization, economic and social transformation. Relative mechanisms, such as household registration system, the private school tuition pricing regulation, the social security and equal career development opportunities of private school teachers, etc., might not be perfect enough to support the market reform in education. This painful reform was reflected in the development of private education in City S, during which new conflicts were initiated. There was a growing sense of impotence of the remaining rural private schools, largely because the change in rural population structure. For urban private schools, high turnover rate of teachers because of unequal treatment on welfare, insurance, academic title evaluation, and growth opportunities posed serious threats. The negative effects of urbanization on the development of private education began to showed up over the past few years, and the "non-elite private schools" or "private schools for students with disadvantaged economic and social background" developed in underdeveloped areas like City S might be maladjusted as the national market for quality education grew more cut-throat. For this reason, the equal treatment of public schools and private schools, the preferential terms regarding to rural private schools, and the close connection between urban community development and education, and the prospects for ordinary private schools without elite characteristics should be taken into account when making education policy decision.

\section{Acknowledgements}

We are very grateful to Dr. Yan Fengqiao in Peking University and Dr. Zhou Haitao in Beijing Normal University for their guidance.

\section{REFERENCES}

[1] The State Council of PRC (1992, June 16). Decision of the Central Committee of the Communist Party of China and the State Council on accelerating development of tertiary industry [Electronic databases of laws of the PRC]. Retrieved from

http://www.asianlii.org/cn/legis/cen/laws/dotccotcpocatscoa doti1228/

[2] Department of Development Planning of Chinese Ministry of Education (2004, September). The thought and policy of Chinese private education Report Outlines [Electronic report]. Retrieved from

[3] http://www.cnsaes.org/homepage/Upfile/2010625/20100625 62188637.pdf

[4] Department of Development Planning of Chinese Ministry of Education (Ed.).(2003). Green paper on non-governmental education in China. Shanghai: Shanghai Education Publishing. 
[5] Tao X.P. (2005). To promote rational transformation of Chinese private education. Exploring Education Development, 20, 5-8.

[6] Wu,H.(2009). On the locally-driven policy model of Chinese private education. Research in Educational Development, 8, $11-16$.

[7] Wu,H.(2009). Michael G.,\& Peter C.(1990).Urban land economics. Beijing:China People's University Press.17.

[8] Urbanization [online forum]. Retrieved from http://en.wikipedia.org/wiki/Urbanization

[9] Davis, K. (1955). The origin and growth of urbanization in the world. American Journal of Sociology, 60(5), 429-437.

[10] Wang B.S.\& Luo Z.Q.(1993). The road and the trend of Chinese urbanization. Beijing: Academy Press.

[11] Henderson, J. V. (2009). Urbanization in China: policy issues and options. China Economic Research and Advisory Programme [Electronic report]. Retrieved from http://webcache.googleusercontent.com/search?q=cache:qOt tPwt2F-gJ:www.econ.brown.edu/faculty/henderson/Final\%2 520Report $\% 2520$ format 1 109summary.doc $+\& \mathrm{~cd}=1 \& \mathrm{hl}=\mathrm{zh}-$ $\mathrm{CN} \& \mathrm{ct}=\mathrm{clnk} \& \mathrm{gl}=\mathrm{cn}$

[12] Martindale, D. (1984). Theory of the City. In Iverson, N. (Ed.). Urbanism and Urbanization: views, aspects, and dimensions (pp.9-32). Netherlands: Brill Academic Pub.

[13] Van de Mieroop, M. (1997). The ancient Mesopotamian city. Oxford University Press. [13] Wirth, L. (1938). Urbanism as a Way of Life. American journal of sociology,44(1), 1-24.

[14] United Nations Department of Economic, \& Social Affairs Population Division. (2008). World urbanization prospects: the 2007 revision. United Nations Publications. Cited from Haub, C. (2009). What is a city? What is urbanization? [online article]. Retrieved from http://www.prb.org/Publications/Articles/2009/urbanization. aspx

[15] Kamal-Chaoui, L., Leman, E., \& Zhang, R. (2009). Urban trends and policy in China (No. 2009/1). OECD Publishing.
[16] Bartlett, L., Frederick, M., Gulbrandsen, T., \& Murillo, E. (2002). The marketization of education: Public schools for private ends. Anthropology \& Education Quarterly, 33(1), 5-29.

[17] Levaéciâc, R. (1995). Local management of schools: analysis and practice. Buckingham England and Bristol, PA Open University Press.

[18] Bedi, A. S., \& Garg, A. (2000). The effectiveness of private versus public schools: The case of Indonesia. Journal of Development Economics, 61(2), 463-494.

[19] Brownell, S. M. (1962). Education and Urbanization. Journal of Teacher Education, 13(2), 203-207.

[20] Havighurst, R. J. (1967). Urbanization and education in the United States.International Review of Education, 13(4), 393-409.

[21] King, E. (1967). Urbanisation and education in Britain. International Review of Education, 13(4), 431-450.

[22] Biobaku, S. (1967). The effects of Urbanisation on education in Africa: The Nigerian experience. International Review of Education, 13(4), 451-460.

[23] Zhang Z.Z. (2003). The interactive of higher education and regional development---an empirical research in China context. Exploring Education Development, 9,39-44.

[24] Wang S.F.(2006).Higher education and regional economy. Beijing: Economic Science Press. 1.

[25] Wen J.H., \& Han Y.Q.(2012). The correlation of urbanization and higher education. Urban Studies, 19(5), color plates 1-4.

[26] Yang D.P.(2012). Rapid urbanization and dismantling teaching points and combining schools. Chinese News Week. 03-26.

[27] Wang J.T., \& Cui F.Y.(2010). The empirical research of the relationship between China's population on education structure and urbanization. Urban Studies, 17 (12): 24-29.

[28] James, E., \& Rose-Ackerman, S. (2013).The Non-Profit Enterprise in Market Economics. Taylor \& Francis.27-28. 